\title{
Performance of Tomato (Solanum lycopersicum L.) Hybrids under Polyhouse Condition
}

\author{
Mohan Singh*, K. D. Ameta, R. A. Kaushik, Rajkumar Jat and Kuldeep Singh Rajawat \\ Department of Horticulture, Rajasthan College of Agriculture, MPUAT, \\ Udaipur-313001, Rajasthan, India \\ *Corresponding author
}

\begin{abstract}
A B S T R A C T
Keywords

Tomato, Polyhouse, growth, Yield, hybrids

Article Info

Accepted: 07 April 2019 Available Online: 10 May 2019

An experiment entitled "Performance of Tomato (Solanum lycopersicum L.) Hybrids under Polyhouse Condition" was conducted at Hi-Tech Unit, Department of Horticulture, Rajasthan College of Agriculture, MPUAT, Udaipur during the year 2017-18 to find out the best tomato hybrid under polyhouse condition. The experiment was laid out in completely randomized design with nine hybrids replicated four times. The analysis of variance revealed significant variation among the hybrids for all the characters. The experiment results revealed that hybrid Dev was performed extremely well under polyhouse condition with respect to growth and yield parameters viz., stem diameter at 90 days $(0.75 \mathrm{~cm})$ and at final harvest $(1.21 \mathrm{~cm})$, leaf area per plant $\left(321.95 \mathrm{~cm}^{2}\right)$, per cent fruit set $(82.45 \%)$ and yield characteristics like fruit per plant (59.59) and yield per plant $(5.50 \mathrm{~kg})$. On the basis of present investigation, it can be inferred that hybrid Dev was high yielding and can be recommended as better hybrids for commercial cultivation under polyhouse condition in Udaipur, Rajasthan.
\end{abstract}

\section{Introduction}

Tomato (Solanum lycopersicum L.) is one of the most important members of Solanaceae family and widely grown across the globe. It originated and domesticated in the Andean region of the South America and in Mexico from the wild ancestor of Lycopersicon sub. Species cerasifoeme (Bai and Lindhout, 2017). A study suggested that tomato contains an antioxidant lycopene, which markedly reduces the risk of prostate cancer (Kucuk, 2001). It is a good appetizer having pleasing taste (Ram, 1991). Consumption of tomato and its products can significantly reduces the risk of developing of colon, rectal and stomach cancer. Based on its nutritive value and presence of lycopene and flavonoids it is mostly considered as 'protective food' (Sepat et al., 2013). In the world during 2014-15 the total area under tomato cultivation is 4.81 million hectares with a production of 163.02 million MT and productivity was 33.9 MT per hectare in the world. India is the second largest producer $(11.5 \%)$ of tomato in the world. In India, tomato was grown in area of 
8.09 lakh hectares with a production of 196.97 lakh MT and productivity of 24.34 MT per hectare (Anon., 2017). Protected cultivation is a unique and specialized form of agriculture in which the microclimate surrounding the plant is controlled partially or fully, as per the requirement of the plant species grown during their growth period (Mishra et al., 2010). Polyhouse cultivation of tomato offers distinct advantages of earliness, higher productivity and quality particularly pesticide residue free produce, besides higher returns to growers.

Under protected environment the natural environment is modified to the suitable conditions for optimum plant growth which ultimately helps in the production of quality tomato suitable for export and domestic consumption (Singh and Sirohi, 2006). Occurrence of frost coupled with low temperature during the month of December and January causes mortality of tomato plant when grown in open field condition, but under protected environment, the yield loss can be minimized. India being a vast country with diverse and extreme agro-climatic conditions, the protected vegetable cultivation technology can be utilized for year round and off-season production of high value, low volume vegetables, production of virus free quality seedlings, quality hybrid seed production and as a tool for disease resistance breeding programs (Wani et al., 2011). Though, the technology for producing quality tomato fruit have been standardized but there is very little information is available on performance of hybrids under polyhouse condition in southern Rajasthan.

\section{Materials and Methods}

Investigation conducted during from August, 2017 to March, 2018 at Hi-Tech Horticulture Unit, Department of Horticulture, Rajasthan College of Agriculture, Udaipur. The size of the polyhouse was $28 \mathrm{~m} \times 32 \mathrm{~m}$ (896 sq. m) covered with aluminate sheet and ultra violet stabilized low density polyethylene sheet have 200 micron thickness. Udaipur is situated at $24^{\circ} 34^{\prime} \mathrm{N}$ latitude and $73^{\circ} 42^{\prime} \mathrm{E}$ longitude at an elevation of 582.17 meter above mean sea level. The region falls under agro climatic zone IV a (Sub-Humid Southern plain and Aravalli Hills) of Rajasthan.

Nine tomato hybrids namely Mahy 302, TO 1057, KSP-1154, Arka Smrat, Emerald, Shahenshah, Dev, Sarthi-044 and Rajesh were included in experiment. The experiment was laid out in a Completely Randomized Design with four replications in naturally ventilated polyhouse. The seeds of tomato were sown in plastic pro-trays having cells of 1.5 inch in size containing growth medium namely coco peat, vermiculite and perlite mixture in the ratio of $3: 1: 1$, respectively.

The beds were prepared having $30 \mathrm{~cm}$ above from ground level and 1 meter width along with length of polyhouse. A row to row and plant to plant spacing of $45 \times 30 \mathrm{~cm}$ respectively, was adopted during investigation. All the agricultural operations were followed as per recommended package and practices. Observations regarding plant height $(\mathrm{cm})$, stem diameter $(\mathrm{cm})$, branches per plant, leaf area per plant $\left(\mathrm{cm}^{2}\right)$, days to flowering, per cent Fruit set, days to first harvesting, clusters per plant, fruits per plant, yield per plant $(\mathrm{g})$ and yield per square meter were recorded.

Five plants were randomly selected per accession per replication for recording observations and the mean worked out. Analysis of variance was done based on CRD as suggested by Panse and Sukhatme (1985) for each of the characters separately. In order to evaluate the most profitable treatment combination, economics of different treatments were worked out in terms of net returns and net returns per rupee investment. 


\section{Results and Discussion}

\section{Plant height (cm)}

Plant height differed significantly among the hybrids at different stages due to varied genetic makeup of different tomato hybrids. The height of plant at 90 days ranged from $161.00 \mathrm{~cm}$ to $246.90 \mathrm{~cm}$ (Table 1).

The mean value for plant height at 90 days was recorded maximum in Mahy-302 (246.90 $\mathrm{cm})$ followed by KSP-1154 $(221.40 \mathrm{~cm})$, whereas height of plant at final harvest ranged from $263.15 \mathrm{~cm}$ to $352.90 \mathrm{~cm}$. Mahy-302 produced tallest plant $(352.90 \mathrm{~cm})$ at final harvest followed by KSP-1154 $(307.60 \mathrm{~cm})$.

Plant height is usually a good index of plant vigour, which may contribute towards greater productivity. The presence of variation in plant height is the result of inherent genetic capacity of hybrids. Variation in plant height was also reported by Sharma and Singh (2015) and Ganesan (2001).

\section{Stem diameter $(\mathrm{cm})$}

The data regarding to the stem diameter at 90 days showed a range of $0.62 \mathrm{~cm}$ to $0.75 \mathrm{~cm}$ (Table 1). The thickest stem at 90 days was seen in Dev $(0.75 \mathrm{~cm})$ which was highly significant and followed by Shahenshah $(0.73$ $\mathrm{cm})$. The highest mean value for stem diameter at final harvest was recorded in Dev $(1.21 \mathrm{~cm})$ which was highly significant and followed by Emerald $(1.17 \mathrm{~cm})$.

\section{Branches per plant}

The number of branches per plant ranged from 6.60 to 8.00 (Table 1). The maximum branches per plant (8.00) were born by hybrids Mahy-302 followed by Shahenshah (7.85). Variation in number of branches was also seen by Gautam et al., (2013).

\section{Leaf area $\left(\mathrm{cm}^{2}\right)$}

The data regarding the leaf area per plant ranged from 286.40 to $321.95 \mathrm{~cm}^{2}$ (Table 1). The maximum leaf area was recorded in Dev $\left(321.95 \mathrm{~cm}^{2}\right)$ and followed by Rajesh $(319.25$ $\left.\mathrm{cm}^{2}\right)$ and Sarthi - $044\left(312.65 \mathrm{~cm}^{2}\right)$ whereas the lowest leaf area per plant $\left(286.40 \mathrm{~cm}^{2}\right)$ was recorded in TO-1057.

\section{Days to first flowering}

The mean number of days from transplanting to first flower initiation varied from 35.55 to 47.60 (Table 2). Among the different hybrids under study, the hybrid Sarthi-044 was earliest in commencement of flowering with value of 35.55 followed by Dev (39.70). This trend of earliness was also seen by Panday et al., (2006) and Chapagain et al., (2011) in tomato. The earliest and late flowering is attributed as genotypic character and somewhat influenced by environmental factor of particularly growing areas. It is also considered to be economically important trait and therefore, assumes significance in crop improvement programmers since the early flowering hybrids and varieties with high yield are usually sought for the commercial cultivation.

\section{Fruit set percentage}

The fruit set percentage was significantly affected by the tomato hybrids. Per cent fruit set was ranged from 74.15 to 82.45 (Table 2). Fruit set percentage on tomato hybrids is one of the important parameters for summer and rainy season tomato production which determines the resistance and tolerance of a hybrid to a particular temperature and environment. The maximum fruit setting $(82.45 \%)$ was recorded in the hybrid Dev which was significantly higher than all the other hybrids tested in the present investigation. KSP-1154 had the lowest fruit 
set percentage $(74.15 \%)$. Pollen viability is one of the essential requirements for maximum fruit set. These findings is in conformity with the findings of Alam et al., (2010) and Panday et al., (2006). The results revealed that the fruit set percentage was directly related to the fruit yield. Higher the fruit set, more would be the fruit yield.

\section{Days to first harvesting}

The data regarding days to first harvesting ranged from 77.75 to 97.95 (Table 2) and hybrid Sarthi-044 stood on first position and earliest hybrid with value of 77.75 followed by Shahenshah (89.15) and Dev (90.95) whereas hybrid Rajesh took maximum days (97.95). The results were in confirmation with Chapagain et al., (2011).

\section{Clusters per plant}

The number of clusters per plant ranged from 6.80 to 9.15 (Table 2). The highest mean value for cluster per plant was recorded in Shahenshah (9.15) followed by Emerald (8.50) whereas the lowest value (6.800) was recorded in TO-1057. Similar ranges have also been reported by Singh et al., (2014) and Chapagain et al., (2011).

\section{Fruits per plant}

Number of fruits per plant is an important yield contributing trait and directly contributes to yield per plant which ranges from 30.26 to 59.59 fruits per plant (Table 2). Hybrid Dev was on the top in order of bearing maximum fruits with mean value of (59.59) whereas on the other hand, hybrid Shahenshah and Mahy-302 were at par with Dev having value of (58.14 and 48.20) respectively. The lowest value (30.26) was found in KSP-1154. Maximum fruit yield per plant of tomato hybrids was due to higher fruit set and higher retention of matured fruit per plant. Similar findings were supported by Cheema et al., (2013).

\section{Yield per plant $(\mathrm{kg})$}

The difference among the hybrids on marketable fruit yield was highly significant. It is evident from data presented in Table 2 that among all tomato hybrids the maximum fruit yield per plant was observed in hybrid Dev $(5.50 \mathrm{~kg})$, which was significantly superior over all the other hybrids studied, followed by Shahenshah $(5.15 \mathrm{~kg})$ and Arka Samrat $(4.32 \mathrm{~kg})$. The hybrid TO-1057 gave the lowest marketable fruit yield $(2.62 \mathrm{~kg})$. Variation in yield per plant was might be due to genetic makeup of the plant, more number of flowers and more fruit set percent because of vigorous and healthy plants. Such kind of genetic differences for marketable fruit yield and other plant characters in different tomato hybrids had also been reported by Jindal et al., (2015) and Singh et al., (2006).

\section{Economics}

Economics return from the seven hybrids showed in Table 3. Comparative economics of the different treatments revealed that hybrid Dev was found best for highest gross return of (Rs. 242200), net return of (Rs. $168155)$ and net return per rupee investment (2.27) and followed by Shahenshah gross return of (Rs. 228700), net return (Rs. $154655)$ and net return per rupee investment (2.09). While minimum gross return, net return and B:C (Rs. 116000, Rs. 41955 and 0.57 respectively) in treatment KSP-1154.

On the basis of results obtained in the present investigation it may be concluded that among the various treatments, cultivar Dev was found superior in vegetative growth and yield parameters such as stem diameter, leaf area, per cent fruit set, number of fruits per plant, total yield per plant. 
Table.1 Performance of tomato hybrids for growth characters under polyhouse condition

\begin{tabular}{|l|l|l|l|l|l|l|}
\hline Hybrids & $\begin{array}{l}\text { Plant } \\
\text { height at 90 } \\
\text { days (cm) }\end{array}$ & $\begin{array}{l}\text { Plant height } \\
\text { at final } \\
\text { harvest }\end{array}$ & $\begin{array}{l}\text { Stem } \\
\text { diameter at } \\
\text { 90 days }(\mathbf{c m})\end{array}$ & $\begin{array}{l}\text { Stem diameter } \\
\text { at final harvest } \\
(\mathbf{c m})\end{array}$ & $\begin{array}{l}\text { Branches } \\
\text { per plant }\end{array}$ & $\begin{array}{l}\text { Leaf area } \\
\left(\mathbf{c m}^{2}\right)\end{array}$ \\
\hline Mahy-302 & 246.90 & 352.90 & 0.71 & 1.14 & 8.00 & 297.90 \\
\hline TO-1057 & 211.88 & 301.65 & 0.63 & 0.93 & 6.95 & 286.40 \\
\hline KSP-1154 & 221.40 & 307.60 & 0.68 & 0.99 & 7.15 & 291.85 \\
\hline Arka Samrat & 198.35 & 299.55 & 0.73 & 1.03 & 7.30 & 299.65 \\
\hline Emerald & 185.25 & 287.75 & 0.65 & 1.17 & 7.30 & 300.85 \\
\hline Shahenshah & 161.00 & 260.50 & 0.73 & 1.15 & 7.85 & 307.60 \\
\hline Dev & 180.00 & 263.15 & 0.75 & 1.21 & 7.35 & 321.95 \\
\hline Sarthi-044 & 189.75 & 276.30 & 0.66 & 1.11 & 7.35 & 312.65 \\
\hline Mahy-302 & 182.90 & 279.10 & 0.70 & 0.95 & 6.60 & 319.25 \\
\hline SEm \pm & 11.367 & 8.477 & 0.005 & 0.056 & 0.234 & 0.429 \\
\hline CD $(\mathbf{P}=\mathbf{0 . 0 5})$ & 33.161 & 24.728 & 0.014 & 0.164 & 0.682 & 1.251 \\
\hline
\end{tabular}

Table.2 Performance of tomato hybrids for yield characters under polyhouse condition

\begin{tabular}{|c|c|c|c|c|c|c|}
\hline Hybrids & $\begin{array}{l}\text { Days to } \\
\text { flowering }\end{array}$ & $\begin{array}{l}\text { Percent fruit } \\
\text { set }\end{array}$ & $\begin{array}{l}\text { Days to first } \\
\text { harvesting }\end{array}$ & $\begin{array}{l}\text { Cluster per } \\
\text { plant }\end{array}$ & $\begin{array}{l}\text { Fruit per } \\
\text { plant }\end{array}$ & $\begin{array}{l}\text { Yield per } \\
\text { plant }(\mathrm{kg})\end{array}$ \\
\hline Mahy-302 & 41.35 & 78.25 & 92.95 & 7.90 & 48.20 & 4.04 \\
\hline TO-1057 & 43.70 & 76.25 & 96.80 & 6.80 & 34.06 & 2.81 \\
\hline KSP-1154 & 45.25 & 74.15 & 95.35 & 6.95 & 30.27 & 2.62 \\
\hline Arka Samrat & 46.25 & 79.50 & 96.90 & 7.90 & 47.80 & 4.32 \\
\hline Emerald & 41.80 & 78.00 & 94.50 & 8.50 & 47.98 & 4.16 \\
\hline Shahenshah & 41.53 & 80.20 & 89.15 & 9.15 & 58.14 & 5.15 \\
\hline Dev & 39.70 & 82.45 & 90.95 & 8.40 & 59.59 & 5.50 \\
\hline Sarthi-044 & 35.55 & 80.60 & 77.75 & 6.95 & 45.53 & 4.23 \\
\hline Mahy-302 & 47.60 & 79.75 & 97.95 & 7.65 & 46.70 & 4.27 \\
\hline SEm \pm & 0.194 & 0.891 & 0.402 & 0.159 & 1.364 & 130.88 \\
\hline $\mathrm{CD}(\mathrm{P}=0.05)$ & 0.566 & 2.600 & 1.173 & 0.465 & 3.979 & 381.82 \\
\hline
\end{tabular}

Table.3 Economics of different hybrids per $1000 \mathrm{~m}^{2}$ area of tomato in polyhouse

\begin{tabular}{|c|c|c|c|c|}
\hline Treatment & $\begin{array}{l}\text { General cost } \\
\text { (Rs) }\end{array}$ & $\begin{array}{l}\text { Gross } \\
\text { returns (Rs) }\end{array}$ & $\begin{array}{l}\text { Net } \\
\text { returns (Rs) }\end{array}$ & B:C ratio \\
\hline Mahy-302 & 74045 & 179300 & 105255 & 1.42 \\
\hline TO-1057 & 74045 & 125000 & 50955 & 0.69 \\
\hline KSP-1154 & 74045 & 116000 & 41955 & 0.57 \\
\hline Arka Samrat & 74045 & 192100 & 118055 & 1.59 \\
\hline Emerald & 74045 & 184900 & 110855 & 1.50 \\
\hline Shahenshah & 74045 & 228700 & 154655 & 2.09 \\
\hline Dev & 74045 & 242200 & 168155 & 2.27 \\
\hline Sarthi-0044 & 74045 & 188100 & 114055 & 1.54 \\
\hline Rajesh & 74045 & 189800 & 115755 & 1.56 \\
\hline
\end{tabular}




\section{Acknowledgements}

I am thankful to Indian council of Agricultural Research, New Delhi for providing me National Talent Scholarship during 2016-18 for my Post Graduation study and authorities of MPUAT, Udaipur.

\section{References}

Alam, M.S., Sultana, N., Ahmed, S., Hossain, M.M. and Islam, A.K.M.A. 2010. Performance of heat tolerant tomato hybrid lines under hot, humid condition. Bangladesh Journal of Agricultural Research, 35(3): 367-373.

Anonymous, 2017. Ministry of agriculture cooperation and farmer welfare, Government of India, New Delhi.

Bai, Y. and Lindhout, P. 2007. Domestication and breeding of tomato: what have we gained and what can we gained in the future? Annals of Botany, 100(5): 10851094

Chapagain, T.R., Khatri, B.B. and Mandal, J.L. 2011. Performance of tomato varieties during rainy season under plastic house condition. Nepal Journal of Science and Technology, 12(2): 1722.

Cheema, D.S., Singh, N. and Jindal, S.K. 2013. Evaluation of indeterminate tomato hybrids for fruit, yield and quality traits under net house and open field conditions. Vegetable Science, 40(1): 45-49

Ganesan M. 2001. Performance of tomato varieties under organic farming in greenhouse and open field conditions during winter season of Tamil Nadu. Madras Agriculture Journal, 88(3): 1012.

Gautam, U.S., Negi, R.S, Singh, R., Kaushik, S.S. and Singh, A. 2013. Participatory evaluation of tomato varieties for commercial cultivation during rainy season under Kaymore Plateau and Satpura Hills - agro-climatic zone of Madhya Pradesh. Journal of Agricultural Science, 5(4): 238-241.

Jindal, S.K., Dhaliwal, M.S. and Chawla, N. 2015. Comparative performance of different tomato hybrids under naturally ventilated polyhouse. International Journal of Horticulture Science, 5(14): $1-12$.

Kucuk, O. 2001. Phase II randomized clinical trial of lycopene supple-mentation before radical prostatectomy. Cancer Epidemiology, Biomarkers and Prevention, 10(4): 861-868.

Mishra, G.P., Singh, N., Kumar, H. and Singh, S.B. 2010. Protected Cultivation for Food and Nutritional Security at Ladakh. Defence Science Journal, 60: 219-225.

Pandey, Y.R., Pun, A.B., Kalika, P. and Upadhyay, K.P. 2006. Participatory varietal evaluation of rainy season tomato under plastic house condition. Nepal Agriculture Research Journal, 7(3): 11-15.

Panse, V. G. and Sukhatme, P. V. 1985. Statistical Method for Agricultural Workers, (3Ed.), ICAR, New Delhi, pp. 145-146.

Ram, H.H. 1991. Text book. Vegetable Breeding Principles and Practices. Kalyani Publishers, pp: 171-187.

Sepat, N.K., Sepat, S.R., Sepat, S. and Kumar, A. 2013. Energy use efficiency and cost analysis of tomato under greenhouse and open field production system at Nubra valley of Jammu and Kashmir. International Journal of Environmental Sciences, 3(4): 12331241.

Sharma, V.K. and Singh, T. 2015 Performance evaluation of tomato (Solanum lycopersicum L.) hybrids for increased productivity under polyhouse conditions in temperate areas. Journal 
of Agriculture and Crops, 1(6): 68-74.

Singh, B. and Sirohi, N.P.S. 2006. Protected cultivation of vegetables in India: problems and future prospects. Proc IS on greenhouses, environmental control and In house mechanization for crop production in the tropics and subtropics. Acta Horticulture, 710(38): 339-342.

Singh, B., Kumar, M. and Hasan, M. 2006 Performance of tomato cultivars under greenhouse conditions in Northern India. Journal of Vegetable Science, 11(4): 73-80.
Singh, T., Singh, N., Bahuguna, A., Nautiyal, M. and Sharma, V.K. 2014. Performance of tomato (Solanum lycopersicon L.) hybrids for growth, yield and quality inside polyhouse under Mid Hill Condition of Uttarakhand, American Journal of Drug Discover, 68(3): 1-8.

Wani, K. P., Singh, P. K., Amin, A., Mushtaq, F. and Dar, Z. A. 2011. Protected cultivation of tomato, capsicum and cucumber under Kasmir valley conditions. Asian Journal of Science and Technology, 1(4): 56-61.

\section{How to cite this article:}

Mohan Singh, K. D. Ameta, R. A. Kaushik, Rajkumar Jat and Kuldeep Singh Rajawat. 2019. Performance of Tomato (Solanum lycopersicum L.) Hybrids under Polyhouse Condition. Int.J.Curr.Microbiol.App.Sci. 8(05): 597-603. doi: https://doi.org/10.20546/ijcmas.2019.805.069 